\title{
SIMULASI MODEL HBV PADA DAERAH ALIRAN SUNGAI BATANG ARAU PADANG
}

\author{
Nofi Yendri Sudiar \\ Jurusan Fisika Universitas Negeri Padang \\ Jl. Prof Dr. Hamka Air tawar Barat Padang. \\ Email: n_sudiar@yahoo.com
}

\begin{abstract}
The objective of the study was to apply and to test the HBV subtropical model into a tropical region Batang Arau watershed Padang. Batang Arau watershed, located in Padang, covers an area of $106 \mathrm{~km}^{2}$. The HBV model was manually calibrated by trial adjustment of each parameter to obtain the appropriate physical characteristics of Batang Arau watershed. The study shows that the correlation coefficient of 0.48 and the value of NSE at 0.58 . The value indicates the HBV modeling included in the category of accuracy being and indicated that HBV built models can not simulate the discharge of DAS Batang Arau quite well and can not be used to represent the real situation in DAS Batang Arau Padang. Although DAS Batang Padang Harau included in a small basin, but the model of HBV have not been able to describe the phenomenon that is properly due to the diversity of topography.
\end{abstract}

Key words: Model HBV hydrology, watershed Batang Arau, the diversity of topography

\section{PENDAHULUAN}

Pemahaman dan pengenalan tentang karakteristik komponen-komponen yang ada didalam suatu Daerah Aliran Sungai (DAS) sangat diperlukan di dalam praktek pengelolaan DAS. Hal ini tidak mudah untuk dilaksanakan secara utuh dan menyeluruh karena setiap komponen tersebut memiliki keragaman/variabilitas secara spasial dan temporal. Interdependensi dan interaksi komponen-komponen DAS merupakan peubah yang berperan mempengaruhi karakteristik umum dari sistem DAS, dan terjadi dalam suatu kesetimbangan dinamis sehingga pola dan sifat interaksi dan interdependensinya juga selalu berubah. Oleh karena itu ilmu pengetahuan selalu mencoba mengembangkan dan menggunakan sistem modeling dalam pendekatan pengelolaan DAS untuk membantu memahami sifat dan perubahan sifat dari komponen-komponen tersebut.

Menurut Pawitan (2000) pendekatan analisis sistem dalam kajian hidrologi DAS merupakan landasan teori yang sangat ampuh dalam mengintegrasikan informasi komponen- komponen suatu sistem DAS menjadi modelmodel hidrologi DAS. Hal ini telah dirasakan kebutuhan akan teknik pemodelan hidrologi yang mampu mengevaluasi dan menduga secara cepat dampak hidrologi dari perubahan dan tindakan pengelolaan tertentu yang terjadi di dalam suatu DAS. Model hidrologi demikian akan merupakan dasar bagi teknologi pengelolaan DAS yang rasional, efektif dan efisien, yaitu dengan kemampuan eksperimentasi dan simulasi dengan komputer.

Menurut Hillel (1977), model simulasi merupakan teknik numerik dari percobaan hipotetik dari suatu gejala atau sistem dinamis dan dinyatakan secara kuantitatif. Sedangkan Brooks et al. (1987) menyatakan bahwa model hidrologi merupakan gambaran sederhana dari suatu sistem hidrologi yang aktual. Model hidrologi dibuat untuk mempelajari fungsi dan respon suatu DAS dari berbagai masukan DAS. Melalui model hidrologi dapat dipelajari kejadian-kejadian hidrologi yang pada gilirannya dapat digunakan untuk memprediksi kejadian hidrologi yang akan terjadi.Persamaan dasar yang menjadi landasan bagi semua analisis 
hidrologi adalah persamaan neraca air (water balanced equation). Persamaan neraca air dari suatu DAS untuk suatu periode dapat dinyatakan dengan persamaan berikut (Harto 1993):

$$
\begin{aligned}
& \quad \mathbf{I}-\mathbf{O}=\Delta \mathbf{S} \\
& \text { Dimana }: \mathrm{I}=\text { masukan }(\text { inflow }) \\
& \mathrm{O}=\text { Keluaran (outflow) } \\
& \Delta \mathrm{S}=\text { Perubahan tampungan } \\
& \text { (storage change) }
\end{aligned}
$$

Berbagai model simulasi hidrologi telah banyak dikembangkan di negara maju, untuk menerangkan proses perubahan masukan hujan menjadi keluaran berupa debit aliran sungai dengan mempertimbangkan karakteristik fisik DAS. Model simulasi hidrologi pada dasarnya dibuat untuk menyederhanakan sistem hidrologi, sehingga perilaku sebagian komponen di dalam sistem dapat diketahui. Parameter yang diperlukan sebagai data masukannya pun lebih sederhana, mudah diukur dan cepat diperoleh hasil keluarannya. Model semacam ini diharapkan dapat digunakan untuk memecahkan masalah pada suatu DAS yang kurang lengkap atau tidak tersedia datanya, seperti halnya kebanyakan DAS di Indonesia. Pada praktikum kali ini model yang digunakan adalah model Hydrologiska Byråns Vattenbalansavdelning (HBV).

ModelHBV(Hydrologiska Byråns Vattenbalansavdelning) (Bergström, 1976, 1992) adalah modelcurah hujan-limpasan (rainfall-runoff model), yang mencakup deskripsikonseptualnumerikdariproses

hidrologipada skalaDAS.Model ini pertama kali dikembangkan oleh Swedish Meteorological and Hydrological Institut untuk membantu operasi PLTA (Kopenen et al, 2010). Dalam versi yang berbeda model HBV telah diterapkan di lebih dari 40 negara di seluruh dunia. Model HBV telah diterapkan pada negara-negara dengan kondisi iklim yang berbeda seperti misalnya Swedia, Zimbabwe, India dan Kolombia. Model ini telah diterapkan untuk skala mulai dari plot lysimeter (Lindström dan Rodhe, 1992) ke seluruh cekungan drainase Laut Baltik (Bergström dan Carlson, 1994; Graham, 1999).

Tujuan penelitian ini adalah untuk menganalisa simulasi debit dengan model HBV di DAS Batang Arau.

\section{METODE}

\section{Lokasi}

Lokasi yang digunakan untuk simulasi model HBV adalah Daerah aliran sungai (DAS) Batang Arau di Kota Padang. DAS Batang Arau ini berada pada posisi $0^{\circ} 48^{c e}-0^{\circ} 56^{\text {ee }} \mathrm{LS}$ dan $100^{\circ} 21$ - $100^{\circ} 33^{\text {ce }} \mathrm{BT}$, dengan ketinggian 0 $1.853 \mathrm{~m}$ dari permukaan laut (dpl). DAS Batang Arau berbatasan dengan DAS Batang Kuranji di bagian Utara, di sebelah selatan dengan DAS Timbalun dan DAS Batang Tarusan, sebelah Timur dengan Kabupaten Solok dan di sebelah barat dengan Samudera Indonesia. Secara keseluruhan luas DAS ini sebesar $106 \mathrm{~km} 2$ dengan sumber air yang berasal dari sungai Lubuk Paraku, Sungai Padang Idas dan sungai Lubuk Sarik. Sungai utama DAS ini adalah sungai Batang Arau yang mengalir melalui kota Padang dan bermuara di Pantai Muaro dan Pantai Purus (Banda Bakali). Lokasi DAS Batang Arau ditampilkan pada Gambar 1.

\section{Data dan Model HBV}

Model terdiri dari berbagai macam routing salju/hujan, air tanah, evapotranspirasi, dan air bumi dengan 3 persamaan linier reservoir dan channel routing. (Seibert, 1997). Untuk daerah tropis yang tidak mengalami curahan berupa salju, HBV model membagi lapisan tanah menjadi 3 dan 1 channel routing berdasarkan respon tanah terhadap hujan. Empat lapisan tersebut diantaranya yaitu: X1 (Soil Moisture Storage), X2 (Upper Storage), X3 (Lower Storage/Ground Water) dan X4 (Aliran air sungai). 
Nofi Yendri Sudiar, Simulasi Model HBV pada Daerah Aliran Sungai Batang Arau Padang

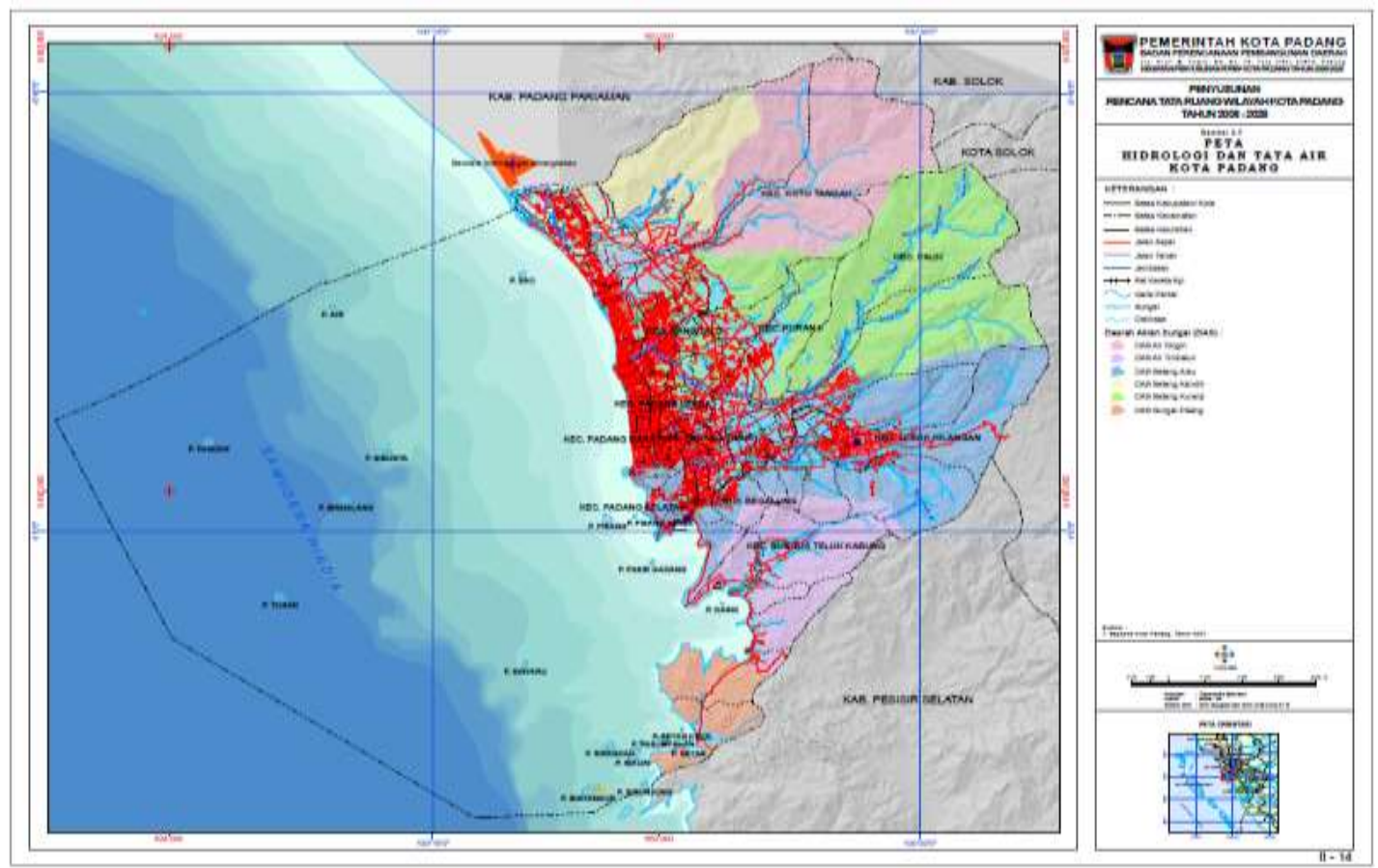

Gambar 1 Lokasi Daerah Aliran Sungai Batang Arau, Padang

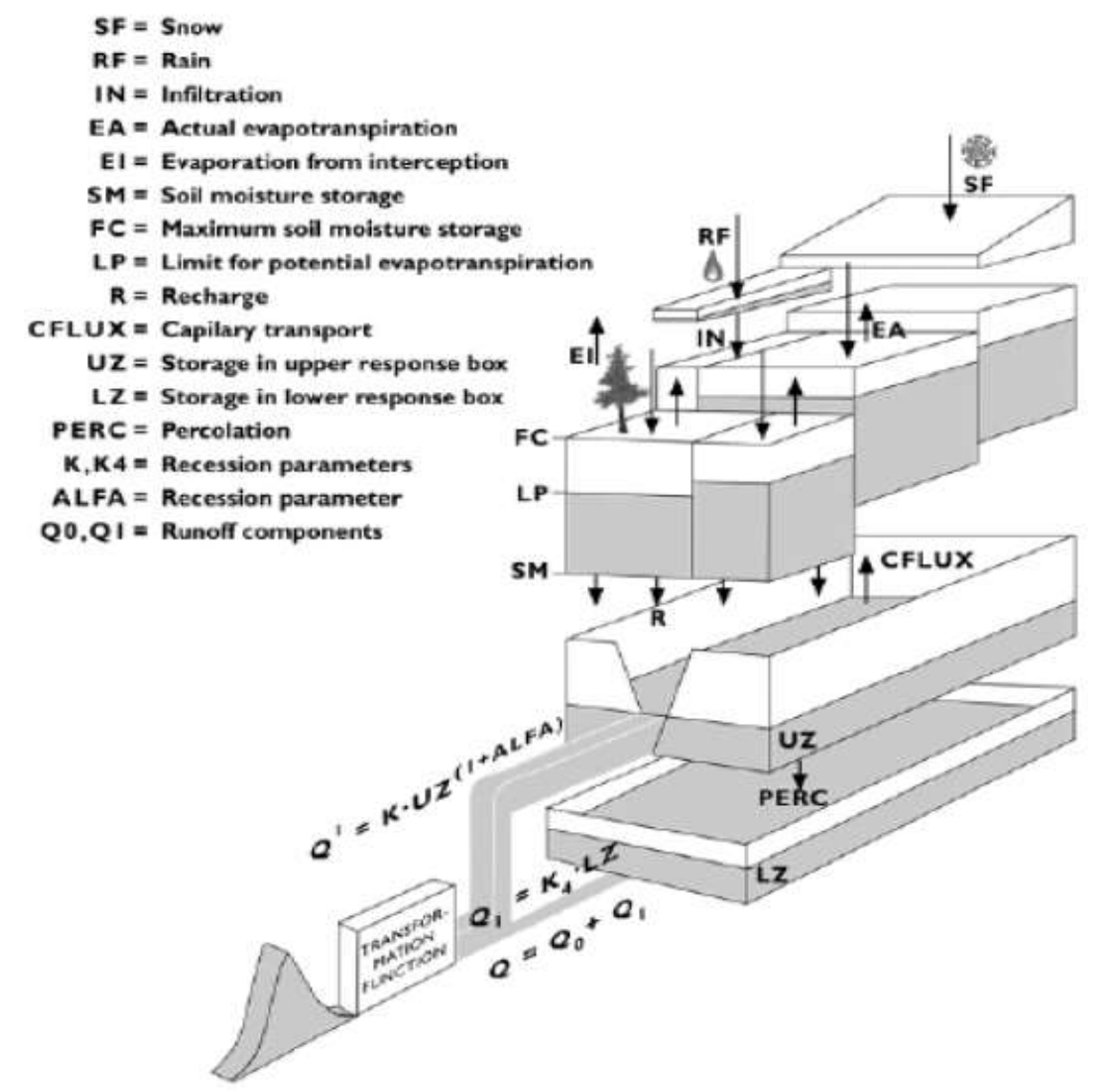

Gambar 2 Sistem Model HBV (SMHI 2006) 
Dalam simulasi model HBV, digunakan empat parameter utama yaitu a) curah hujan kumulatif, b) kelembaban tanah, c) evapotranspirasi dan d) limpasan permukaan. Model HBV telah dikembangkan oleh Hundecha dan Bardossy (2004) dan AghKouchak dan Habib (2010) menjadi model ensembel HBV yang terdiri dari lima model meliputi : (1) Pencairan dan akumulasi salju, (2) lengas tanah dan dan hujan efektif, (3) evapotranspirasi, (4) respon runoff dan (5) simulasi ensembel (AghKouchak et al 2013).

Data curah hujan harian dan suhu yang digunakan untuk membangun model adalah data pengukuran tahun 1991 dari stasiun BMKG Ladang Padi, sedangkan data pengukuran debit air atau limpasan permukaan adalah data tahun yang sama yang diukur di pos duga air milik Dinas Pekerjaan Umum Provinsi Sumatera Barat (Gambar 3).

\section{Curah Hujan Efektif}

Curah hujan merupakan komponen penting dalam hidrologi karena merupakan satusatunya sumber air di suatu Daerah Aliran Sungai (DAS). Curah hujan bervariasi menurut waktu dan ruang. Variasi menurut waktu ditandai dengan adanya pergantian musim, sedangkan variasi menurut ruang dipengaruhi oleh adanya uap air, letak geografi dan elevasi setempat.Hujan yang jatuh ke suatu daerah aliran sungai akan terbagi menjadi dua komponen, yaitu infiltrasi dan aliran permukaan. Pemisahan dari kedua komponen ini dilakukan berdasarkan ketersediaan kandungan air tanah. Kandungan air tanah maksimum disebut dengan kapasitas lapang (Field Capacity). Jika kandungan air tanah semakin mendekati kapasitas lapang maka infiltrasi akan berkurang dan semakin banyak air hujan yang akan menjadi aliran permukaan. Besarnya curah hujan efektif dapat dihitung menggunakan persamaan berikut:

$$
P_{E f f}=\left(\frac{S M}{F C}\right)^{\beta} P
$$

Dimana $P_{E f f}$ adalah curah hujan efektif, $S M$ adalah kandungan air tanah (Soil Moisture),
FC adalah kapasitas lapang (Field Capasity) dan $\beta$ adalah parameter model (koefisien kemiringan). Koefisien aliran akan semakin kecil jika nilai $\beta$ besar pada kandungan air tanah tertentu dan hal ini juga berlaku sebaliknya.

Nilai $\beta$ dan kapasitas lapangadalah parameter kalibrasi dari model HBV.Nilai koefisien aliran permukaan serta kandungan air tanah dapat berubah dan tidak konstan.Pertambahan kandungan air tanah melalui infiltrasi akan membuat nilai ini akan terus berubah setelah terjadinya hujan, jika tidak ada hujan maka kandungan air tanah juga bisa berubah karena terjadinya evapotranspirasi. Untuk menjalankan perhitungan atau simulasi model membutuhkan nilai kandungan air tanah awal.

\section{Evapotranspirasi}

Evapotranspirasi merupakan proses gabungan antara evaporasi dengan transpirasi. Evaporasi adalah air yang hilang dari tanah sekeliling tanaman, permukaan daun dan permukaan air. Transpirasi adalah air yang masuk ke dalam akar tanaman dan di gunakan tanaman atau air yang hilang melalui daun ke atmosfir (Hansen et al. 1986).

Data evapotranspirasi potensial dihitung menggunakan metode pendugaan Thornwaite dengan memasukan parameter suhu rata-rata bulanan $(\mathrm{Tm})$. Metode ini dipilih berdasarkan ketersediaan data pada stasiun iklim yang tersedia.Rumus pendugaan Thornwaite (1948) mengikuti persamaan sebagai berikut ( Bautista and Carranza, 2009):

$$
E T o=1.62\left(10 x \frac{T m}{I}\right)^{a}
$$

$$
\begin{aligned}
& I=\sum i \quad \text { dengan } \quad i=\left(\frac{T m}{5}\right)^{1.514} \text { dan } \\
& a=0.49239+1792-771 \times 10^{-7} I^{2}+675 \times 10^{-9} I^{3}
\end{aligned}
$$




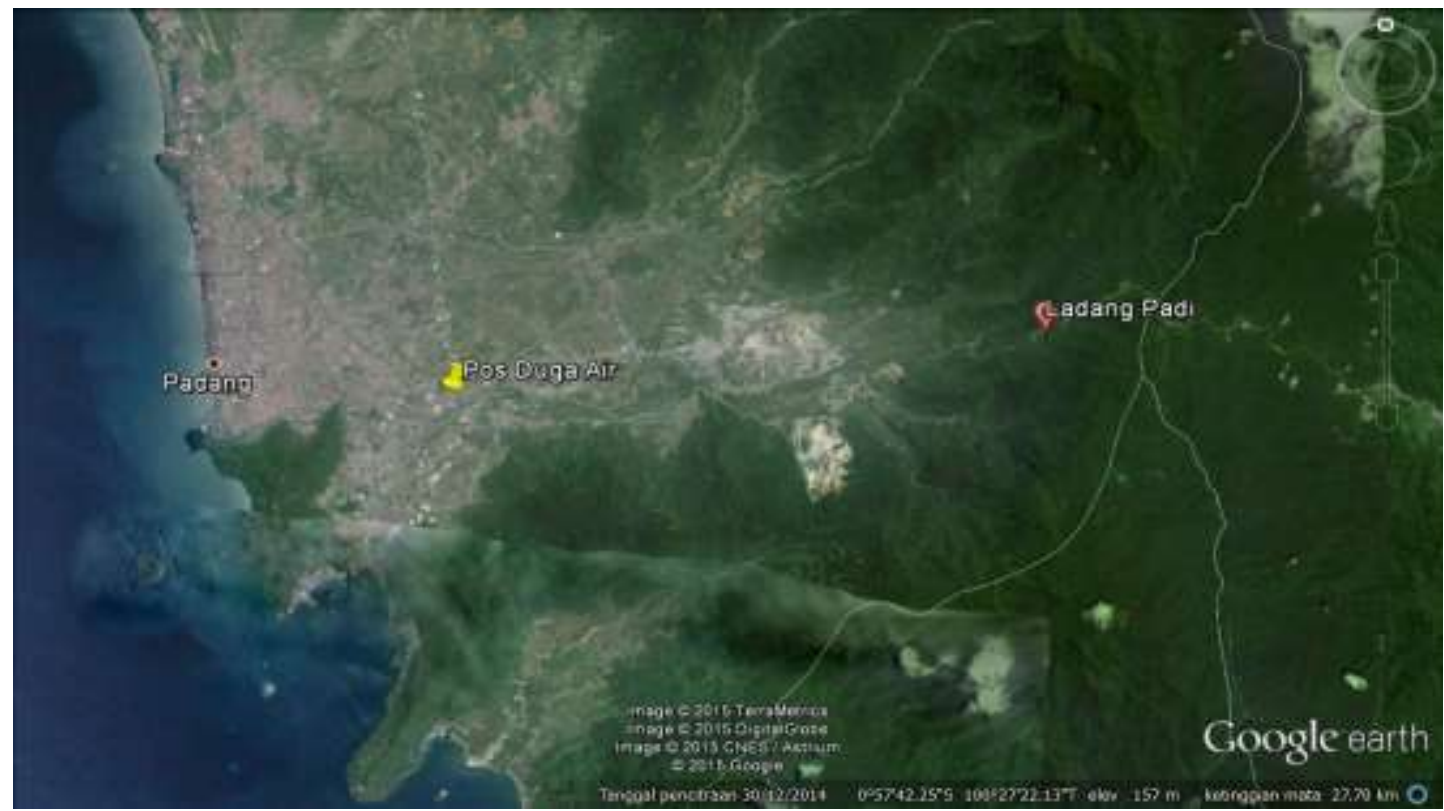

Gambar 3 Stasiun pengukuran curah hujan dan suhu (Stasiun BMKG Ladang Padi) serta pengukuran debit sungai utama DAS Batang Arau (Pos Duga Air - PU).

Gambaran aliran model HBV ditampilkan pada Gambar 4. Pada model HBV ini, input curah hujan kumulatif diasumsikan terjadi secara merata di seluruh kawasan DAS. Hal yang sama juga diasumsikan untuk jenis dan kelembaban tanah yang dianggap sama untuk seluruh kawasan. Input curah hujan dihitung secara harian.

Terdapat tiga komponen yang menjadi penentu dalam besaran jumlah output atau debit air yang terukur. Komponen-komponen tersebut adalah limpasan permukaan (surface runoff), interflow dan baseflow. Limpasan permukaan akan dipengaruhi oleh jumlah curah hujan, koefisien kelembaban tanah dan perkolasi. Jumlah air hujan yang sampai ke permukaan tanah akan menjadi limpasan apabila tidak terserap oleh bagian tanah di bawahnya. Banyaknya interflow dan baseflow akan tergantung pada koefisien resesi pada masingmasing komponen.

\section{Kalibrasi Model}

Banyak model parameter yang dapa diubah dalam model HBV, model parameter yang dapat diubah secara bebas hingga mendapatkan hasil model terbaik. Tahapan kalibrasi dan validasi yang dilakukan antara lain
(1) metode kalibrasi yang digunakan adalah automatic dan trial and errors; (2) melakukan kalibrasi secara trial and errors (manual) dengan menjalankan a dynamic update checkbox, list of calibration parameter, update graph; (3) melakukan kalibrasi secara otomatis (generic calibration) dan (4) melakukan validasi model.

Setelah proses kalibrasi dan validasi dilakukan akan diperoleh nilai range parameter yang dapat memberikan hasil kalibrasi yang optimal. Kriteria statistik yang digunakan adalah koefisien korelasi, nash sutcliffe coefficient dan bias, dimana kalibrasi yang optimal akan menghasilkan nilai $\mathrm{R}^{2}$ mendekati satu dan sebaliknya bias akan mendekati nol. Persamaan yang digunakan adalah Nash-Sutcliffe Efficiency (NSE) sebagai berikut:

$$
\begin{gathered}
N S E=1- \\
\left(\frac{\sum\left(Q_{\text {input }}-Q_{\text {observasi }}\right)^{2}}{\sum\left(Q_{\text {observasi }}-Q_{\text {rata }}\right)^{2}}\right) \ldots \ldots \ldots \ldots \ldots \\
\text { Bias }=\frac{\sum(m(i)-o(i))}{n}
\end{gathered}
$$

Parameter DAS yang telah dikemukakan sebelumnya mungkin perlu dimodifikasi untuk menghasilkan hidrograf yang paling sesuai 
antara model dan pengukuran.Nilai NSE $>0.7$ atau $70 \%$ dapat dikatakan mempunyai tingkat akurasi sangat tinggi sehingga hasil simulasi model dapat digunakan, apabila nilai NSE $<0,7$ maka simulasi harus diulang kembali.
Setelah menyelesaikan proses kalibrasi dan validasi maka grafik yang diharapkan dari pemodelan yaitu terdapat kecocokan antara runoff terukur dan terhitung sehingga dapat menunjukkan tingkat kevalidan pemodelan dan ketepatan pengolahandata.

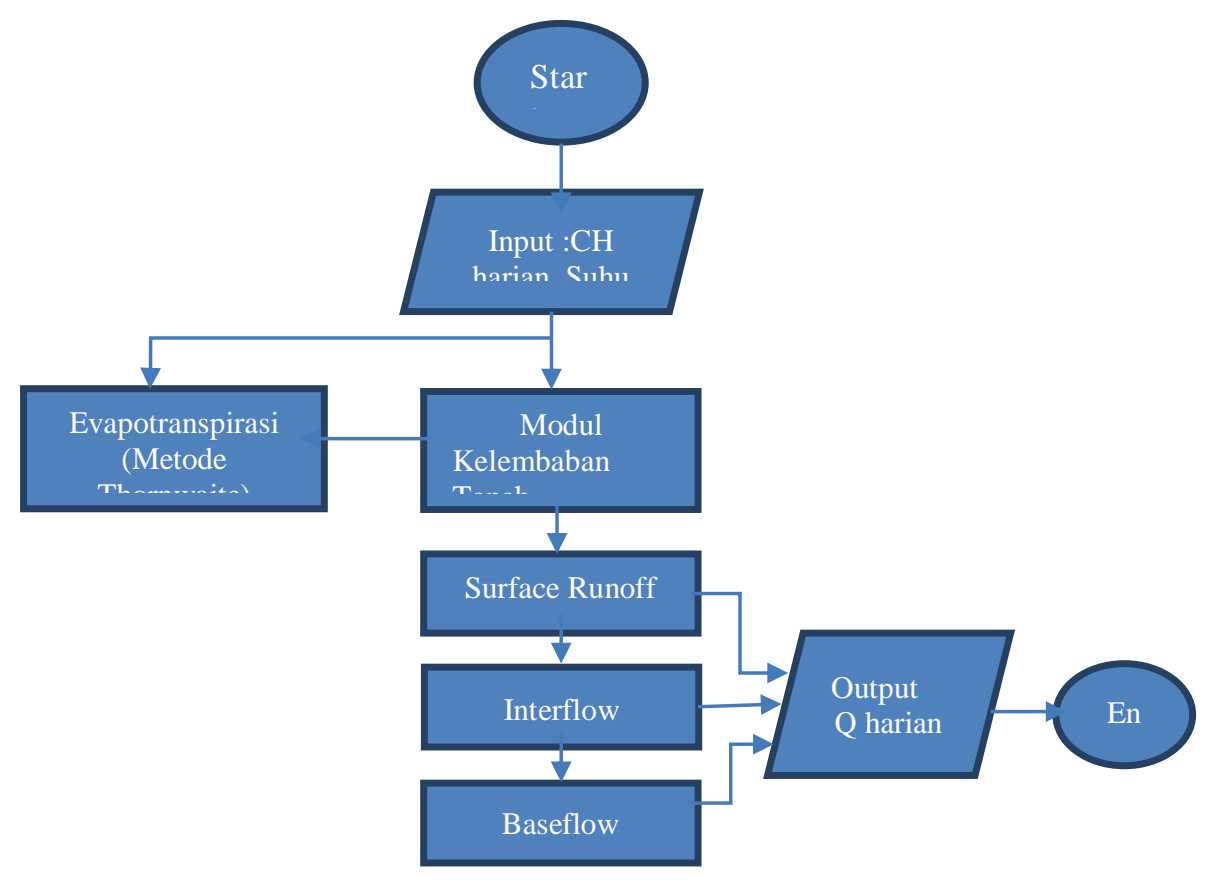

Gambar 4. Algoritma model HBV

\section{HASIL DAN PEMBAHASAN}

\section{Kondisi Umum DAS Batang Arau}

Dari hulu ke hilir, penggunaan lahan di DAS ini cukup beragam. Di hulu, DAS berupa hutan baik hutan lindung maupun hutan suaka wisata. Di bagian tengah sampai hilir, DAS dimanfaatkan sebagai lahan pertanian/perkebunan, pemukiman, pertambangan dan industri seperti semen dan pabrik karet.

Material tanah DAS ini tersusun dari material yang bervariasi namun didominasi oleh jenis podsolik (ultisol). Tanah podsolik adalah tanah yang terbentuk karena kondisi curah hujan yang tinggi dan suhu yang rendah. Daya simpan unsur hara di jenis tanah ini sangat rendah dan kandungan organik biasanya hanya terdapat di permukaan tanah. Selain itu, daya simpan air sangat rendah sehingga mudah mengalami kekeringan.

Penggunaan sumberdaya air DAS Batang Arau terarah pada berbagai macam kebutuhan yaitu kebutuhan rumah tangga, kebutuhan pertanian/perkebunan, kebutuhan perkotaan dan kebutuhan industri. Seiiring dengan peningkatan penduduk di daerah sepanjang DAS ini maka secara otomatis, terjadi peningkatan kebutuhan air baik untuk kebutuhan keluarga, perkotaan, pertanian maupun industri. Tahun 2009, kebutuhan air perkotaan sebesar 14,5 juta $\mathrm{m}^{3} /$ tahun dan diproyeksikan akan meningkat menjadi $32 \mathrm{~m}^{3} /$ tahun pada tahun 2028 .

\section{Hasil Simulasi}

Simulasi model HBV menghasilkan keluaran berupa debit aliran harian selama satu tahun. Data input berupa data curah hujan tahun 1991 dan data suhu tahun 1991. Debit hasil 
simulasi model dibandingkan dengan hasil pengukuran pada tahun yang sama. Kehandalan model dalam simulasi dinilai berdasarkan nilai NSE dan $\mathrm{R}^{2}$.
Hasil simulasi debit model HBV pada DAS Batang Arau Padang yang dilakukan dapat dilihat pada hidrograf Gambar 5.

Tabel 1 parameter input pada simulasi debit model HBV pada DAS Batang Arau Padang

\begin{tabular}{ccc} 
& yang digunakan & \\
\hline & Nilai Parameter & $\mathbf{4 0 0}$ \\
FC & & $\mathbf{3}$ \\
Beta & & $\mathbf{0 , 1}$ \\
CFLUX & $\mathbf{0 , 0 3}$ \\
KUZ1 & $\mathbf{2 0}$ \\
L & $\mathbf{0 , 0 0 9}$ \\
KUZ2 & $\mathbf{0 , 0 0 2}$ \\
KLZ & $\mathbf{0 , 0 8}$ \\
PERC & $\mathbf{9 0}$ \\
PWP & & \\
\hline
\end{tabular}

Sumber : Hasil Uji Coba

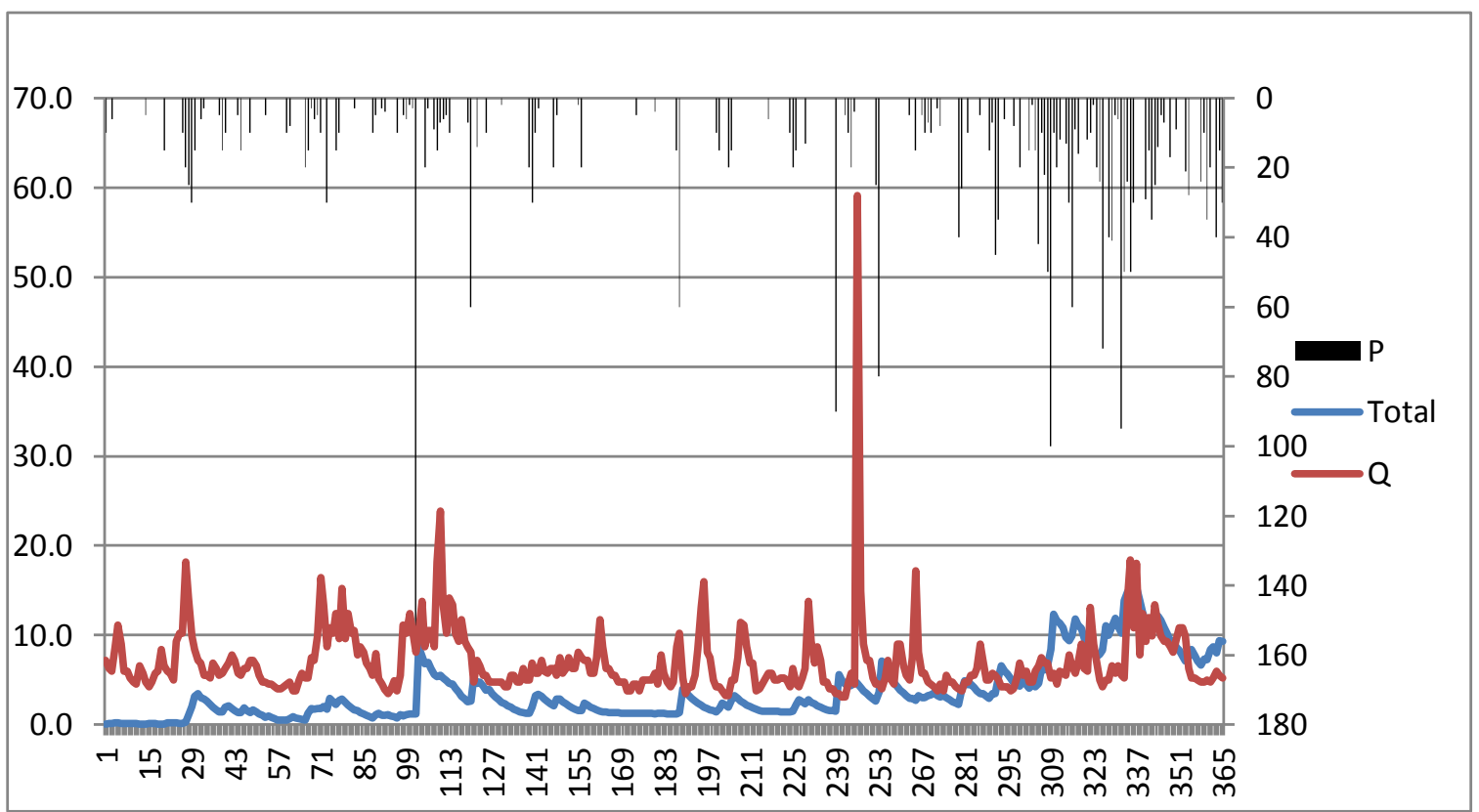

Gambar 5 Hidrograf Hasil Simulasi debit tahun 1991

Adapun Hasil kalibrasi model dengan menggunakan Nash-Sutcliffe Efficiency (NSE) dan persentase bias antara debit hasil pengukuran dan simulasi model HBV tahun 1991 dengan nilai koefisien korelasi sebesar 0,48 dan nilai NSE sebesar 0.58 .
Nilai NSE yang diperoleh adalah $0,58 \mathrm{hal}$ ini menunjukkan pemodelan $\mathrm{HBV}$ tersebut masuk dalam katagori akurasi sedang dan mengindikasikan bahwa model HBV yang dibangun belum dapat mensimulasikan debit dari DAS Batang Arau dengan cukup baik dan 
belum bisa dipakai untuk mewakili keadaan sebenarnya pada DAS Batang Arau Padang.

Untuk mendapatkan nilai korelasi dan NSE, dilakukan penyesuaian (adjustment) pada nilai-nilai parameter yang ada. Dari 9 parameter tersebut, pengaturan nilai aliran atas dan tengah memberikan dampak yang cukup signifikan pada aliran debit akhir model.

Namun demikian, pengaturan dari parameter-parameter tersebut ternyata belum menghasilkan nilai optimal seperti yang diharapkan dimana hasil debit model akan sesuai dengan hasil pengukuran debit di lapangan. Salah satu faktor yang membuat tidak optimalnya pengaturan parameter model adalah nilai akhir model menggambarkan hasil kumulatif dari jumlah presipitasi yang masuk ke sistem DAS. Dengan demikian, model akan memberikan gambaran debit yang terus meningkat sampai ke akhir pegukuran. Sementara itu, nilai pengukuran debit di lapangan menunjukkan bahwa aliran debit dengan variabilitasnya tetap menunjukkan nilai yang hampir sama sepanjang waktu. Perbedaan ini membuat pengukuran model di awal tahun akan underestimate sementara di akhir tahun akan overestimate.

Belum bagusnya nilai korelasi dan NSE ini juga dapat diakibatkan oleh adanya nilai ekstrim pada komponen input terutama curah hujan. Kondisi ekstrim berpengaruh pada kondisi limpasan dan debit total observasi. Sementara itu, model yang dibangun tidak dapat menangkap kondisi ekstrim ini sehingga terjadi perbedaan nilai observasi dan simulasi.

Selain hal tersebut, nilai korelasi dan NSE juga menggambarkan bahwa hasil simulasi yang dilakukan dengan model HBV belum mewakili kondisi DAS Batang Harau yang sebenarnya. Hal ini diakibatkan oleh keberagaman topografi DAS yang bervariasi dari 0 mdpl sampai > 1000 mdpl. Tiga stasiun penakar hujan (Ladang Padi, Simpang Alai dan Teluk Bayur) yang dijadikan sebagai perhitungan curah hujan wilayah ternyata belum mampu menggambarkan sebaran hujan di wilayah DAS Batang Harau. Sangat beralasan kenapa topografi menjadi hal yang sangat penting, karena wilayah kota Padang yang menghadap Samudera Hindia dan disebelah timur membentang Bukit Barisan sering mengalami hujan orografi. Fenomena inilah sepertinya yang belum dapat ditangkap oleh model HBV. Sehingga tiga stasiun penakar hujan sangat tidak memadai untuk dijadikan sebagai data input curah hujan kawasan DAS ini. Untuk wilayah DAS yang tidak homogen ini, model HBV ternyata tidak dapat menjelaskan dengan baik nilai debitnya. Dibutuhkan perhitungan lanjutan yang bisa mewakili parameter topografi. Sebagai saran, mungkin parameter HBV ditambah input nya dengan faktor topografi.

\section{KESIMPULAN}

Hasil simulasi model HBV belum mampu menggambarkan nilai debit aliran DAS Batang Arau tahun 1991 dengan nilai koefisien korelasi sebesar 0.48 dan nilai NSE sebesar 0.58. Berdasarkan nilai tersebut, pemodelan HBV masuk dalam katagori akurasi sedang dan mengindikasikan bahwa model HBV yang dibangun belum dapat mensimulasikan debit dari DAS Batang Arau dengan cukup baik dan belum bisa dipakai untuk mewakili keadaan sebenarnya pada DAS Batang Arau Padang.

Meskipun DAS Batang Harau Padang termasuk dalam wilayah DAS yang kecil, namun model HBV belum mampu menggambarkan fenomena yang ada dengan baik yang disebabkan oleh keberagaman topografi.

\section{DAFTAR KEPUSTAKAAN}

Agha Kouchak A, N Nakhjiri dan E Habib. (2013). An educational model for ensemble streamflow simulationand uncertainty analysis. Hydrol. Earth Syst. Sci., 17, 445-452. Dapat diakses di :10.5194/hess-17-445-2013.

AghaKouchak, A., Bardossy, A., and Habib, E. (2010). Copula-based un-certainty modeling: Application to multi-sensor precipitation es-timates, Hydrol. Process., 24, 2111-2124.

Bautista f dan C Dellago Carranza. (2009). Calibration of the equations of Hargreaves and Thornthwaite to estimate the potential evapotranspiration in semi-arid and subhumid tropical climates for regional applications. Atmosfera 22(4), 331-348 
Bergström, S. (1992). The HBV model - its structure and applications. SMHI Reports RH, No. 4, Norrköping.

Hansen VE, IsraelenOW, StringhamGE. (1979). Irrigation Principles and Practices. John Wiley and Sons, New York (US).

Harto, S. (1993). Analisis Hidrologi.Gramedia Pustaka Utama, Jakarta (ID).

Hillel, D. (1971). Soil and Water, Physical Principle and Processes. Academic Press. New York (US).

Nash, J.E., Sutcliffe, J.V. (1970). River flow forecasting through conceptual models.
Part I - A discussion of principles. Journal of Hydrology, Vol. 10(3), pp. 282-290.

Pawitan, H. (2000). Hidrologi Daerah Aliran Sungai: Teknik Pemodelan danSimulasiSistem DAS. MakalahPelatihan Agroklimatologi. Jurusan Geofisika dan Meteorologi, FMIPAIPB Bekerjasama

BagproPeningkatan Sdm Ditjen DiktiDepdiknas. Bogor, 14-26 Agustus2000.

SMHI. (2006). Integrated Hydrological Model System Manual. SMHI 